\title{
Evaluasi Kinerja Cakupan Layanan Trayek Angkutan Perkotaan di Kota Administrasi Jakarta Barat
}

\author{
Arini Dewi Lestari, Raidedo Silalahi \\ Politeknik Transportasi Darat Indonesia-STTD \\ Email: arinidewi.lestari@ptdisttd.ac.id
}

\begin{abstract}
Road traffic and transportation is a vital part of the transportation side. There are still many areas that have not been served by public transportation, causing accessibility difficulties in these areas. Therefore, it is necessary to improve the performance of the urban transportation route network in the administrative city of West Jakarta. Therefore, this study aims to reach urban transportation route services in the administrative city of West Jakarta. In completing this Compulsory Working Paper, the author uses a comparative or comparative research methodology. Research Results It is still necessary to rearrange the city transportation tray because there are still areas that have not been served around the Taman Sari sub-district. After setting the average walking distance of people to public transportation facilities, which was originally $355.35 \mathrm{~m}$, changed to $345.97 \mathrm{~m}$, the coverage of urban transportation services in the West Jakarta Administrative City which was originally $90 \%$ changed to $94 \%$ so that it can be seen that accessibility in unserved areas has increased.

Keywords: Performance, Route Service, Urban Transport
\end{abstract}

\begin{abstract}
Abstrak
Lalu lintas dan angkutan jalan merupakan salah satu bagian yang vital dalam sisitiom transportasi. Masih banyaknya daerah yang belum terlayani angkutan umum menyebabkan terjadinya kesulitan aksesibilitas didaerah tersebut. Oleh sebab itu perlu dilakukan peningkatan kinerja jaringan trayek angkutan kota di wilayah kota administrasi Jakarta Barat. Oleh sebab itu penelitian bertujuan untuk mengevaluasi kinerja cakupan layanan trayek angkutan perkotaan di Kota administrasi Jakarta Barat. Dalam penyelesaian Kertas Kerja Wajib ini, penulis menggunakan metodologi penelitian yang bersifat komparatif atau perbandingan. Hasil Penelitian Masih perlu dilakukan penataan ulang terhadap trayek angkutan kota karena masih adanya daerah yang belum terlayani di seputaran kecamatan Taman sari. Setelah adanya penataan rata rata jarak berjalan kaki orang ke fasilitas angkutan umum yang semula adalah $355,35 \mathrm{~m}$ berubah menjadi 345,97 m, Cakupan pelayanan angkutan perkotaan di Kota Administrasi Jakarta Barat yang semula sebesar $90 \%$ berubah menjadi 94\% sehingga terlihat aksesbilitas pada daerah belum terlayani meningkat.
\end{abstract}

Kata Kunci: Kinerja, Layanan Trayek, Angkutan Perkotaan.

\section{A. PENDAHULUAN}

Lalu lintas dan angkutan jalan merupakan bagian dari sistem transportasi yang menempati posisi vital (Siahaan \& Salomo, 2012). Kota sebagai pusat kegiatan merupakan satu kesatuan dinamis dimana masing-masing kegiatan atau aktifitas tersebut tidak bisa dipisahkan. Keterkaitan antara aktifitas-aktifitas tersebut menghendaki suatu sistem jaringan angkutan yang bisa memberikan kemudahan pergerakan bagi penduduk kota. Jaringan trayek angkutan kota diharapkan mampu menyediakan kinerja yang baik bagi pengguna jasa angkutan kota. Sektor angkutan kota tersebut harus mampu memberikan kemudahan (aksesibilitas) demi terciptanya keseimbangan antara jasa yang ditawarkan dengan permintaan akan jasa transportasi.

Jaringan trayek angkutan kota yang telah ditetapkan di Kota Administrasi Jakarta Barat belum dapat melayani setiap aktivitas masyarakat dengan baik. Hal ini dapat dilihat dari masih adanya wilayah dengan kepadatan jaringan trayek yang rendah. Hal ini menunjukkan bahwa masih sedikitnya trayek angkutan kota yang melayani wilayah tersebut. Wilayah yang belum terlayani angkutan kota tersebut menyebabkan cakupan 
pelayanan dan aksesibilitas pada daerah tersebut menjadi buruk bagi pengguna jasa. Aksesibilitas yang rendah pada wilayah tersebut akan menurunkan tingkat kemudahan dalam mencapai daerah tersebut.

Jaringan trayek angkutan kota yang telah ditetapkan di Kota Administrasi Jakarta Barat belum dapat melayani setiap aktivitas masyarakat dengan baik. Hal ini dapat dilihat dari masih adanya wilayah dengan kepadatan jaringan trayek yang rendah. Hal ini menunjukkan bahwa masih sedikitnya trayek angkutan kota yang melayani wilayah tersebut. Wilayah yang belum terlayani angkutan kota tersebut menyebabkan cakupan pelayanan dan aksesibilitas pada daerah tersebut menjadi buruk bagi pengguna jasa. Aksesibilitas yang rendah pada wilayah tersebut akan menurunkan tingkat kemudahan dalam mencapai daerah tersebut.

Moda angkutan umum merupakan salah satu perlengkapan pergerakan baik orang maupun barang. Kota Administrasi Jakarta Barat dilayani oleh berbagai jenis angkutan umum seperti angkutan kota, busway,dan bus sekolah. Sedangkan untuk pergerakan regional dari kota ini dapat ditempuh dengan menggunakan angkutan antar kota antar propinsi (AKAP) berupa bis.

Berdasarkan data yang dimiliki oleh Dinas Perhubungan Kota Administrasi Jakarta Barat, jumlah trayek angkutan kota yang beroperasi di wilayah Kota administrasi Jakarta Barat yaitu sebanyak 26 trayek. Akan tetapi, terdapat 4 trayek yang sudah tidak beroperasi yaitu trayek B05, B07, B07A, dan B12. Sehingga jumlah trayek yang masih beroperasi yaitu sejumlah 22 trayek. Berikut ini merupakan daftar trayek angkutan kota di wilayah Kota Administrasi Jakarta Barat.

Tabel 1. Daftar Trayek Angkutan Kota di Wilayah Jakarta Barat

\begin{tabular}{|c|c|c|c|c|}
\hline NO & $\begin{array}{l}\text { KODE } \\
\text { TRAYEK }\end{array}$ & RUTE YANG DILAYANI & $\begin{array}{c}\text { PANJANG } \\
\text { TRA YEK }\end{array}$ & STATUS \\
\hline 1 & $\mathrm{JB} 03$ & Tanah abang-Grogol & 11.60 & AKTIF \\
\hline 2 & $\mathrm{~B} 01$ & GROGOL - MUARA ANGKE & 11,70 & AKTIF \\
\hline 3 & $\mathrm{~B} 02$ & CENGKARENG - KOTA & 10,54 & AKTIF \\
\hline 4 & $\mathrm{~B} 03$ & CITRALAND - MERUYA & 13,75 & AKTIF \\
\hline 5 & $\mathrm{~B} 04$ & KALIDERES - KEBON JERUK & 14,33 & AKTIF \\
\hline 6 & $\mathrm{~B} 06$ & KAPUK KAMAL - KOTA & 14,53 & AKTIF \\
\hline 7 & $\mathrm{~B} 08$ & RAWA BUAYA - GROGOL & 11,80 & AKTIF \\
\hline 8 & $\mathrm{~B} 09$ & GREEN GARDEN - KREO & 11,70 & AKTIF \\
\hline 9 & $\mathrm{~B} 10$ & TAMAN KOTA - BUDI LUHUR & 17,12 & AKTIF \\
\hline 10 & B11 & RAWA BUAYA - KAMAL & 16,60 & AKTIF \\
\hline 11 & $\mathrm{~B} 17$ & CITRALAND - KEBAYORAN LAMA & 12,30 & AKTIF \\
\hline 12 & M09 & TN. ABANG - KEBAYORAN & 9,30 & AKTIF \\
\hline 13 & M09A & TN. ABANG - KEBAYORAN & 11,20 & AKTIF \\
\hline 14 & M10 & TN. ABANG - JEMBATAN LAMA & 8,25 & AKTIF \\
\hline 15 & M11 & TN ABANG - MERUYA & 11,10 & AKTIF \\
\hline 16 & M13 & KALIDERES - KAPUK & 8,10 & AKTIF \\
\hline 17 & M24 & PS. SLIPI - SRENGSENG & 13,40 & AKTIF \\
\hline 18 & M25 & GROGOL - KOTA & 6,70 & AKTIF \\
\hline 19 & M41 & GROGOL - TOKO TIGA & 6,70 & AKTIF \\
\hline 20 & M43 & GROGOL - ANGKE & 5,15 & AKTIF \\
\hline
\end{tabular}

Lanjutan tabel $1 \ldots .$. 


\begin{tabular}{|c|c|c|c|c|}
\hline NO & $\begin{array}{c}\text { KODE } \\
\text { TRAYEK }\end{array}$ & RUTE YANG DILAYANI & $\begin{array}{c}\text { PANJANG } \\
\text { TRAYEK }\end{array}$ & STATUS \\
\hline 21 & M45 & GROGOL - PS TOMANG & 8.20 & AKTIF \\
\hline 22 & M48 & RAWA BUAYA - CIPULIR & 16,70 & AKTIF \\
\hline 23 & B05 & - & - & TIDAK AKTIF \\
\hline 24 & B07 & - & - & TIDAK AKTIF \\
\hline 25 & B07 A & - & - & TIDAK AKTIF \\
\hline 26 & B12 & - & - & TIDAK AKTIF \\
\hline
\end{tabular}

Berdasarkan daftar trayek tersebut maka masih ada sebagian wilayah di Kota administrasi Jakarta Barat yang belum terlayani oleh angkutan kota.

Dari kondisi tersebut maka di Kota Administrasi Jakarta Barat perlu diadakan pengkajian lebih lanjut mengenai evaluasi jaringan trayek yang baik. Dengan adanya analisa ini, diharapkan dapat meningkatkan aksesibilitas dan kinerja jaringan trayek angkutan perkotaan. Sehingga Judul Kertas Kerja Wajib (KKW) yang diambil adalah "Evaluasi Kinerja Cakupan Layanan Trayek Angkutan Perkotaan di Kota Administrasi Jakarta Barat".

\section{B. METODE}

Dalam penyelesaian artikel jurnal ini, penulis menggunakan metodologi penelitian yang bersifat komparatif atau perbandingan. Penulisan ini dilakukan untuk membandingkan persamaan dan perbedaan dua atau lebih fakta-fakta dan bersifat objek yang diteliti berdasarkan kerangka pemikiran tertentu. Data yang dipakai dalam penelitian ini merupakan data sekunder yang berupa peta jaringan proyek, peta jaringan jalan, data angkutan umum dan survey-survey. Sedangkan teknis analisa data adalah analisa kinerja jaringan proyek yakni jarak antar rute,cakupan pelayanan,nisbah panjang trayek terhadap luas wilayah,dan aksesibilitas.

\section{HASIL DAN PEMBAHASAN Analisa Kinerja Jaringan Trayek eksisting}

Dari data yang diperoleh maka dilakukan analisa sesuai dengan kriteria atau indikator yang telah ditentukan.

a. Jarak Antar Rute

Dalam hal ini diartikan jarak berjalan orang ke fasilitas angkutan umum. Untuk wilayah perkotaan dengan kepadatan pembangunan yang tinggi jarak berjalan antara rute angkutan sebaiknya tidak melebihi $800 \mathrm{~m}$. Sedangkan untuk wilayah pinggiran atau kepadatan rendah, jarak antar rute angkutan umum sebaiknya $1600 \mathrm{~m}$. Dari hasil penelitian dapat diketahui bahwa Trayek B09 memiliki jarak antar rute terbesar yaitu sebesar 789,67 m , sedangkan trayek M43 memiliki jarak antar rute terkecil pada zona sebesar 40,91 m. Jarak berjalan kaki rata rata di Kota Administrasi Jakarta Barat adalah sebesar 355,35 m. Semakin kecil jarak antar rute nya, maka kinerja jaringan trayek nya semakin baik.

b. Cakupan Pelayanan

Cakupan pelayanan jaringan trayek angkutan umum di ukur berdasarkan jarak berjalan, tetapi bukan antar rute pelayanan melainkan ke perhentian. Jaringan pelayanan dikatakan baik jika cakupan pelayanan daerah perkotaan adalah $70 \%$ sampai $75 \%$ penduduk tinggal 400 meter berjalan ke perhentian. Sedangkan untuk daerah pinggiran kota dengan kepadatan 50\% sampai 60\% penduduk tinggal pada jarak berjalan 800 meter ke perhentian. Cakupan pelayanan (area coverage) merupakan kemauan berjalan kaki $(0,4 \mathrm{~km})$ di kanan dan kiri trayek. Sedangkan Panjang trayek yang dihitung dalam 
perhitungan cakupan pelayanan ini apabila ada lintasan yang tumpang tindih hanya dihitung sekali. Untuk perhitungan cakupan pelayanan per zona, panjang trayek yang dipakai adalah total panjang trayek yang melalui zona tersebut. Dari tabel diatas dapat diketahui bahwa Zona yang memiliki cakupan pelayanan tertinggi yaitu zona 5 sebesar $25,4 \mathrm{~km}^{2}$. Dan cakupan pelayanan terendah adalah zona 8 sebanyak $0,7 \mathrm{~km}^{2}$. Semakin besar cakupan pelayanan suatu trayek maka semakin besar pula cakupan wilayah yang terlayani pada zona tersebut.

c. Nisbah Panjang Trayek Terhadap Luas Wilayah

Nisbah ini mengukur panjang jalan yang dilalui pelayanan angkutan di wilayah tersebut dengan luas wilayah daerah yang dilayani. Indikator ini digunakan untuk mengetahui tingkat ketersediaan angkutan kota dalam suatu zona. Dari hasil penelitian diketahui bahwa zona yang memiliki tingkat kepadatan jaringan terbesar yaitu zona 6 sebesar $2,48 \mathrm{~km} / \mathrm{km}^{2}$. Sementara zona dengan tingkat kepadatan jaringan terendah yaitu zona 8 sebesar $0,12 \mathrm{~km} / \mathrm{km}^{2}$.

\section{d. Aksesibilitas}

Aksesibilitas ditunjukan dalam peta kontur waktu angkutan umum. Peta kontur waktu memasukkan unsur jaringan pelayanan/trayek dan aspek operasional pelayanan. Komponen yang dipertimbangkan adalah; waktu berjalan/ jarak berjalan ke fasilitas angkutan umum, waktu menunggu angkutan umum, dan waktu perjalanan. Pada aksesibilitas ini, CBD yang digunakan adalah terminal grogol sedangkan trayek yang masuk ke terminal grogol diantarnya B08, B01, M25, M43, M41, M45. Berikut merupakan cara dalam mendapatkan nilai dari komponen yang dipertimbangkan dalam pembuatan peta kontur waktu.

Menghitung waktu jalan kaki dari rute angkutan umum tersebut ke kisi (grid) diatas peta tersebut. Untuk menghitung waktu jalan kaki ini, kita terlebih dahulu mengukur berapa jarak dari rute angkutan umum terdekat ke kisi (grid). Kemudian dengan mengamsumsikan bahwa kecepatan berjalan kaki ini adalah 100 meter/menit atau waktu per grid nya sebesar 3 menit. Waktu menunggu adalah waktu yang digunakan untuk menunggu mendapatkan pelayan angkutan umum jika frekuensi angkutan umum dari suatu rute diketahui, maka waktu menunggu rata-rata adalah setengah dari headway-nya. Waktu di dalam kendaraan adalah waktu yang digunakan diatas kendaraan dimana sangat dipengaruhi oleh kecepatan kendaraan. Dari kecepatan kendaraan, kita dapat mencari berapa waktu yang dibutuhkan angkutan umum untuk melewati satu kisi (grid).

\section{Pemecahan Masalah}

Dari OD matriks asal tujuan perjalanan yang menggunakan angkutan umum mengetahui potensi permintaan dalam menentukan trayek. Selain itu, penentuan rute trayek dilihat juga dari pola tata guna lahan dan cakupan pelayanan pada wilayah tersebut. OD matriks asal tujuan yang ditampilkan merupakan hasil dari survei wawancara penumpang angkutan umum, sehingga data yang ditampilkan sudah merupakan demand angkutan umum.

a. Matriks OD. Berdasarkan data dari Laporan Umum Tim PKL Kota Jakarta Barat 2017, wilayah studi Kota Administrasi Jakarta Barat dibagi menjadi 13 zona yang terdiri dari 8 zona internal dan 5 zona eksternal.

b. Rute Trayek usulan. Angkutan kota diprioritaskan untuk melayani daerah yang potensial demandnya tinggi. Tapi di sisi lain, angkutan kota diharapkan dapat menjangkau seluruh wilayah kota, sehingga aksesibilitas daerah tersebut tinggi dan dapat mendorong peningkatan wilayah tersebut. Oleh karena itu, penataan jaringan trayek harus memperhatikan wilayah yang belum terlayani atau wilayah dengan aksesibilitas rendah.

Berikut merupakan usulan penataan jaringan trayek 
1. Usulan 1 : Restrukturisasi Trayek M41. Pada tabel matriks asal tujuan (OD) diatas terlihat tarikan yang cukup besar pada zona 8 . Pada kenyataannya, zona 8 sebagian besar belum terlayani angkutan kota. Hal ini menunjukkan bahwa pelayanan angkutan kota belum tersebar secara merata. Ini merupakan pertimbangan utama dalam penataan jaringan trayek. Pada kondisi eksisting, daerah pelayanan trayek M41 meliputi zona 1 , zona 6 , dan zona 8 . Tapi pada kenyataannya,nisbah jaringan trayek pada zona 8 masih sangat rendah yang mengakibatkan aksesibilitas yang buruk sementara permintaan menuju zona 8 cukup besar. Selain itu ,trayek M41 merupakan trayek terdekat dengan zona 8 dimana akan lebih mudah dalam penataan untuk menjangkau permintaan di zona tersebut. Hal ini menjadi pertimbangan dalam menata trayek tersebut. Pada usulan ini, trayek M41 direstrukturisasi dengan memperpanjang trayek ke zona 8 untuk meningkatkan kemerataan cakupan pelayanan angkutan kota. Restrukturisasi ini dilakukan hanya pada rute keberangkatannya saja. Hal ini dimaksudkan agar permintaan pada trayek tersebut pada saat sebelum penataan tetap dapat terlayani

2. Usulan 2 :Restrukturisasi Trayek M25. Pada tabel matriks asal tujuan (OD) diatas juga terlihat tarikan yang cukup besar pada zona 8. Pada kenyataannya, zona 8 sebagian besar belum terlayani angkutan kota. Hal ini menunjukkan bahwa pelayanan angkutan kota belum tersebar secara merata. Ini merupakan pertimbangan utama dalam penataan jaringan trayek. Pada kondisi eksisting, daerah pelayanan trayek M25 meliputi zona 1 dan zona 6 sementara nisbah jaringan pada zona 8 masih sangat rendah yang mengakibatkan aksesibilitas yang buruk sementara permintaan menuju zona 8 cukup besar. Selain itu, trayek M25 memiliki tingkat tumpang tindih yang tinggi sehingga menjadi pertimbangan restrukturisasi untuk melayani zona 8. Pada usulan ini, trayek M25 direstrukturisasi dengan dialihkan ke zona 8 untuk meningkatkan kemerataan cakupan pelayanan angkutan kota di zona tersebut.

\section{Evaluasi Kinerja Jaringan Trayek Setelah Penataan}

a. Jarak Antar Rute

Jarak antar rute diartikan jarak berjalan orang ke fasilitas angkutan umum. Indikator ini menunjukkan tingkat kemudahan untuk mendapatkan fasilitas angkutan umum. Semakin kecil jarak antar rute maka semakin baik kinerja jaringan trayeknya. Dari hasil penelitian dapat dilihat bahwa pada usulan penataan, jarak berjalan kaki rata rata pada trayek M25 menjadi 124,97 m dan jarak berjalan kaki rata rata pada trayek M41 menjadi 79,95 m serta jarak berjalan kaki rata rata seluruh trayek juga menjadi 345,97 m b. Cakupan Layanan

Cakupan Pelayanan merupakan salah satu indikator kinerja jaringan trayek yang menunjukkan persentase pelayanan jaringan trayek pada wilayah tersebut. Semakin besar cakupan pelayanan semakin besar persentase wilayah tersebut telah dilayani angkutan umum.Berikut merupakan cakupan pelayanan jaringan trayek usulan. 
Tabel 2 Cakupan Pelayanan Setelah Penataan

\begin{tabular}{|c|c|c|c|}
\hline \multirow[t]{2}{*}{ ZONA } & $\begin{array}{c}\text { Panjang } \\
\text { Trayek } \\
\text { (km) }\end{array}$ & $\begin{array}{c}\text { Area } \\
\text { Coverage } \\
\text { (km) }\end{array}$ & $\begin{array}{c}\text { Cakupan } \\
\text { Pelayanan } \\
\text { (km2) }\end{array}$ \\
\hline & (i) & (j) & (i) $\times(j)$ \\
\hline 1 & 20,80 & 0,8 & 16,6 \\
\hline 2 & 14,00 & 0,8 & 11,2 \\
\hline 3 & 26,40 & 0,8 & 21,1 \\
\hline 4 & 23,90 & 0,8 & 19,1 \\
\hline 5 & 31,70 & 0,8 & 25,4 \\
\hline 6 & 14,20 & 0,8 & 11,36 \\
\hline 7 & 15,40 & 0,8 & 12,3 \\
\hline 8 & 6,70 & 0,8 & 5,4 \\
\hline \multicolumn{3}{|c|}{ Total } & 122,48 \\
\hline
\end{tabular}

c. Nisbah Panjang Jaringan Terhadap Luas Wilayah

Nisbah pelayanan angkutan umum juga menjadi salah satu indikator penilaian jaringan trayek pada suatu wilayah. Semakin besar nisbahnya maka semakin baik jaringan trayeknya karena mampu menjangkau seluruh bagian wilayah studi.

Tabel 3 Nisbah Panjang Trayek terhadap Luas Wilayah Setelah Penataan

\begin{tabular}{|c|c|c|c|}
\hline Zona & $\begin{array}{c}\text { LUAS WILAYAH } \\
\left(\mathbf{K m}^{\mathbf{2}}\right)\end{array}$ & $\begin{array}{c}\text { PANJANG } \\
\text { TRAYEK (KM) }\end{array}$ & $\begin{array}{c}\text { Nisbah Panjang } \\
\text { Trayek Terhadap } \\
\text { Luas Wilayah } \\
\left(\mathbf{K m} / \mathbf{K m}^{\mathbf{2}} \mathbf{)}\right.\end{array}$ \\
\hline 1 & 9,99 & 20,80 & 2,08 \\
\hline 2 & 7,51 & 14,00 & 1,86 \\
\hline 3 & 17,98 & 26,40 & 1,47 \\
\hline 4 & 24,16 & 23,90 & 0,99 \\
\hline 5 & 26,54 & 31,70 & 1,19 \\
\hline 6 & 5,4 & 14,20 & 2,63 \\
\hline 7 & 30,23 & 15,40 & 0,51 \\
\hline 8 & 7,73 & 6,70 & 0,87
\end{tabular}

Dari tabel diatas dapat dilihat bahwa hasil penataan jaringan trayek telah menambah nisbah zona 6 dan zona 8 .

d. Aksesbilitas

Setelah melakukan penataan juga diperlukan penilaian terhadap indikator aksesibilitas untuk kemudahan dalam mencapai suatu wilayah dengan menggunakan angkutan umum.

\section{KESIMPULAN}

Dari analisis yang telah dilakukan berkaitan dengan kinerja jaringan trayek angkutan kota di Kota Administrasi Jakarta Barat, dapat disimpulkan bahwa Jaringan trayek yang ada saat ini belum dapat memberikan pelayanan yang baik bagi masyarakat, 
dimana masih terdapat zona yang belum dilayani angkutan kota yaitu zona 8 (Kecamatan Taman Sari). Untuk itu perlu dilakukannya penataan untuk menjangkau daerah yang belum terlayani. Setelah penataan jaringan trayek, rata-rata jarak antar rute atau rata rata jarak berjalan kaki orang ke fasilitas angkutan umum yang semula adalah $355,35 \mathrm{~m}$ berubah menjadi 345,97 m. Hal ini menunjukkan bahwa setelah penataan, rata-rata jarak antar rute membaik karena semakin kecil jarak antar rute, semakin dekatlah jarak berjalan kaki yang harus di tempuh pengguna jasa menuju fasilitas angkutan umum. Cakupan pelayanan angkutan perkotaan di Kota Administrasi Jakarta Barat yang semula sebesar $90 \%$ berubah menjadi $94 \%$ setelah penataan. Hal ini menunjukkan bahwa cakupan layanan angkutan perkotaan semakin baik dimana persentase daerah yg dilayani semakin besar. Ketersediaan pelayanan angkutan umum pada suatu daerah dapat dilihat dari nilai nisbah panjang trayek terhadap luas wilayahnya, dimana semakin kecil nilainya, ketersediaan pelayanan angkutan umum juga semakin kecil. Pada kondisi eksisting, nisbah panjang trayek terhadap luas wilayah pada zona 6 (Kecamatan Tambora) adalah sebesar 2,48 km/km² dan pada zona 8 (Kecamatan Taman Sari) adalah sebesar 0,12 $\mathrm{km} / \mathrm{km}^{2}$. Tapi setelah penataan, nisbah panjang trayek terhadap luas wilayah pada kedua wilayah tersebut membaik. Dimana pada zona 6 (Kecamatan Tambora) meningkat menjadi 2,63 km/ $\mathrm{km}^{2}$ dan pada zona 8 (Kecamatan Taman Sari) meningkat menjadi 0,87 $\mathrm{km} / \mathrm{km}^{2}$. Hal ini menunjukkan bahwa ketersediaan pada kedua zona tersebut semakin membaik. Aksesibilitas Setelah penataan, dapat dilihat bahwa aksesibilitas pada daerah yang belum terlayani meningkat. Hal ini ditunjukkan dari angka peta kontur pada tiap grid yang semakin mengecil. Dimana angka angka tersebut mewakili waktu untuk mencapai tiap tiap grid dari CBD. Semakin kecil angkanya berarti waktu yang dibutuhkan untuk mencapai tempat tersebut semakin singkat dan menunjukkan aksesibilitas ke tempat tersebut semakin baik.

\section{REFERENSI}

1. Giannopoulus, G. A.1989, Bus Planning and Operation In Urban Areas, A Practical Guide, Avebury, Gower Publishing Company Ltd, England.

2. Republik Indonesia. (2002). Keputusan Menteri Nomor 89 Tahun 2002 Tentang Penetapan Tarif dan Formula Perhitungan Biaya Pokok Angkutan Penumpang dengan Mobil Bus Umum Antar Kota Kelas Ekonomi, Direktorat Jenderal Perhubungan Darat, Jakarta.

3. Republik Indonesia. (2013). Peraturan Menteri Nomor 98 Tahun 2013 Tentang Standar Pelayanan Minimal Angkutan Orang dengan Kendaraan Bermotor Umum dalam Trayek, Direktorat Jenderal Perhubungan Darat, Jakarta.

4. Republik Indonesia. (2014). Peraturan Pemerintah Nomor 74 Tahun 2014 Tentang Angkutan Jalan

5. Republik Indonesia. (2014). Peraturan Pemerintah Nomor 74 Tahun 2014 Tentang Angkutan Jalan, Direktorat Jenderal Perhubungan Darat, Jakarta.

6. Siahaan, F. C., \& Salomo, R. V. (2012). Alokasi Anggaran Belanja Sektor Transportasi dalam Anggaran Pendapatan dan Belanja Daerah Kota Depok tahun Anggaran 2006-2010. Jurnal Transportasi, 12(1).

7. Tamin, Ofyar Z, 2000, Perencanaan dan Permodelan Transportasi, Edisi kedua, Institut Teknologi Bandung, Bandung.

8. Republik Indonesia. (2009). Undang-Undang Nomor 22 Tahun 2009 Tentang Lalu Lintas dan Angkutan Jalan. 